\title{
Aromatherapy and nursing: historical and theoretical conception
}

\author{
Aromaterapia e enfermagem: concepção histórico-teórica \\ Aromaterapia y enfermería: concepción histórico-teórica
}

\author{
Juliana Rizzo Gnatta ${ }^{1,2}$, Leonice Fumiko Sato Kurebayashi ${ }^{1,3}$, Ruth Natalia Teresa Turrini ${ }^{4}$, Maria Júlia Paes da Silva ${ }^{4}$
}

How to cite this article:

Gnatta JR, Kurebayashi LFS, Turrini RNT, Silva MJP. Aromatherapy and nursing: historical and theoretical conception. Rev Esc Enferm USP. 2016;50(1):127-33. DOI: http://dx.doi.org/10.1590/S0080-623420160000100017

${ }^{1}$ Universidade de São Paulo, Escola de Enfermagem, São Paulo, SP, Brazil.

${ }^{2}$ Universidade de São Paulo, Hospital

Universitário, Centro Cirúrgico, São Paulo, SP, Brazil.

${ }^{3}$ Instituto de Terapia Integrada e Oriental, São Paulo, SP, Brazil.

${ }^{4}$ Universidade de São Paulo, Escola de Enfermagem, Departamento de Enfermagem Médico-Cirúrgica, São Paulo, SP, Brazil.

\begin{abstract}
Aromatherapy is a Practical or Complementary Health Therapy that uses volatile concentrates extracted from plants called essential oils, in order to improve physical, mental and emotional well-being. Aromatherapy has been practiced historically and worldwide by nurses and, as in Brazil is supported by the Federal Nursing Council, it is relevant to discuss this practice in the context of Nursing through Theories of Nursing. This study of theoretical reflection, exploratory and descriptive, aims to discuss the pharmacognosy of essential oils, the historical trajectory of Aromatherapy in Nursing and the conceptions to support Aromatherapy in light of eight Nursing Theorists (Florence Nightingale, Myra Levine, Hildegard Peplau, Martha Rogers, Callista Roy, Wanda Horta, Jean Watson and Katharine Kolcaba), contributing to its inclusion as a nursing care practice.
\end{abstract}

DESCRIPTORS

Aromatherapy; Complementary Therapies; Oils, Volatile; Nursing; Nursing Theory.
Corresponding author:

Juliana Rizzo Gnatta

Av. Prof. Lineu Prestes, 2565

Cidade Universitária

CEP 05508-000 - São Paulo, SP, Brazil

juliana.gnatta@gmail.com
Received: 05/25/2015

Approved: 08/29/2015 


\section{INTRODUCTION}

Alternative and complementary therapies of health are defined as any medical system, practice or product that are not part of conventional medical care ${ }^{(1)}$. Under that definition, aromatherapy can be included. The term "complementary" is used when the practice is associated with the traditional medicine of the Occident, complementing the treatment, while the term "alternative" applies when the therapy completely replaces the conventional treatment ${ }^{(1)}$.

From the 1960s, before there was any official use of the term "alternative or complementary health practices", in the counterculture movement there has been increased interest of the Occident population for these practices. The bippie and rock movements in the United States and Europe, which later came to Latin America, proposed trends to get closer to nature and Orientalism ${ }^{(2)}$.

The World Health Organization (WHO) used the term "Alternative Medicine" to describe a wide range of health care practices that are not part of the country's own tradition and are not integrated into the local health system ${ }^{(3)}$. In 2002, WHO defined the Strategic Plan for 2002-2005 to "Traditional Medicine" as any health practice that is considered traditional in one place and that acted as a subsidy to the theory of medicine used in that country ${ }^{(4)}$. In the latest document released by WHO, entitled "Traditional Medicine Strategy 2014-2023", it is described that there should be a re-evaluation of achievements and the development of national policy proposals to ensure people access, quality and safety with respect to health care, especially in relation to Traditional and Complementary Medicine ${ }^{(5)}$.

Since 2006, the application of the term "integrative practices" has emphasized in health. There are different terminologies that are used worldwide to describe what would be the Integrative and Complementary Practices ${ }^{(6)}$. The term "Integrative and Complementary Practices" was first used in Brazil, by the Ministry of Health in 2006, in the document that approved the National Policy on Integrative and Complementary Practices (Politica Nacional de Práticas Integrativas e Complementares - PNPIC) in the Unified Health System, replacing other already existing terms: Non-conventional Medicines ${ }^{(7)}$, Alternative Therapies and Popular Practices ${ }^{(8)}$ and Natural Medicine ${ }^{(9)}$. It is noteworthy that Ordinance No.971 established some health practices as multidisciplinary specialties, namely, Homeopathy, Acupuncture, Medicinal Plants and Herbal Medicine, Social Hydrotherapy and Crenotherapy. However, Aromatherapy, Floral Therapy and other techniques were not covered with such determination ${ }^{(6)}$.

The National Center for Complementary and Integrative Health $(\mathrm{NCCIH})$, one of the centers of the National Institute of Health (NIH) of the United States of America, proposed a classification to integrative therapies into five different categories: 1) mind-body therapies, which are techniques dealing with these interactions, such as meditation, yoga, music therapy, prayer, biofeedback, tai chi chuan, art therapy, among others; 2) biological-based practices, which use substances found in nature, such as vegetable oils (aromatherapy), herbs (herbal medicine), diet therapy, among others; 3 ) manipulative and body-based practices, those which comprise the physical interaction, such as massage therapy, chiropractic, among others; 4) energy medicine, which work with energetic interactions, such as therapeutic touch, Reiki, among others; and 5) whole medical systems: Traditional Chinese Medicine and Ayurvedic medicine $\mathrm{e}^{(1)}$.

Aromatherapy can be defined as the intentional use of Essential Oils (EO) to promote or improve health, well-being and hygiene ${ }^{(10)}$. The term "Aromatherapy" was first used in 1928 by French perfumer Rene Maurice Gattefossé. We found reports in the literature that in his initial studies with $\mathrm{EO}$ for perfumes, Gattefossé would have gone through a working incident. After a burn in his hands during a distillation process in the laboratory, feeling pain, he plunged the affected area in the near jar containing lavender oil. He perceived that in addition to the almost immediate relief from painful sensation, the wound healed quickly, almost without any scars left $\mathrm{f}^{(11)}$.

Overall, aromatherapy has established itself as a science in England and France. For the French, it is considered a medical specialty, while the British understand them as Integrative and Complementary Practices (ICP). This practice is also used in the United States and Australia as complementary, and, culturally, used in Eastern countries as part of Traditional Medicine ${ }^{(11)}$.

In Brazil, Aromatherapy is not regulated as an ICP and do not have any supervisory body. However, there is a Law Project in the Senate, which is filed, in order to regulate the exercise of therapies in general, among them, Aromatherapy, and intends to create Federal and Regional Councils of Therapists ${ }^{(12)}$.

Nursing, as a profession, has recognized health ICP by means of Resolution N ${ }^{\circ} .197$ of 1997 of the Federal Nursing Council (Conselho Federal de Enfermagem - COFEN) as a specialty of this professional area, requiring professionals to complete a course in the specific area in a recognized teaching institution with minimum workload of 360 hours ${ }^{(13)}$. The Holistic Complementary Therapies are reaffirmed as nursing specialties by Resolution No. 389 of $\mathrm{COFEN}^{(14)}$, ensuring the security and support for the professional to develop research in the area of the ICP in general and hence Aromatherapy. Through the support offered by the regulatory body of the profession, Aromatherapy arouses the interest of Nursing to represent a complementary tool to the care process, contributing to a comprehensive and holistic approach to health.

Aromatherapy, historically and worldwide, has been practiced by nurses and, given that in Brazil this category has the support of COFEN for such professional activities, it is important that it is grounded in the principles of Nursing. As the development of Theories in Nursing reflects a movement in the profession towards the autonomy and delimitation of its actions ${ }^{(15)}$, it is necessary to be based according to the practice of Aromatherapy in this context, since the national scientific literature is still in its infancy in this area. In addition, it can be used by Nursing as a tool to help establish 
the rebalancing both in the emotional and physical wellbeing of the individual ${ }^{(16)}$, with the possibility of intervention, representing the application of Theories in care practice.

This study is a theoretical, exploratory and descriptive reflection, aiming to briefly discuss the pharmacognosy of essential oils, the historical trajectory of Aromatherapy in Nursing and support ICP in light of eight Nursing Theories possible of being correlated with Aromatherapy, three already correlated by other authors in previous publications ${ }^{(17)}$ and six other theories proposed by this study, in order to support the inclusion of Aromatherapy in Nursing care practice.

\section{PHARMACOGNOSY OF ESSENTIAL OILS}

Aromatherapy is a ICP which uses volatile concentrates extracted from plants, called Essential Oils (EO), which are natural chemical compounds, complex and highly volatile characterized by a strong aroma and produced as secondary metabolites of aromatic plants ${ }^{(18)}$.

EO are substances with unique chemical properties due to the characteristic of being made of numerous substances, which give them peculiarities that cannot be replaced by other synthetic substances, despite the olfactory similarity. Synthetic products are called "essences" and act in a restricted manner in the body by the fact they have a particular chemical composition, while the $\mathrm{EO}$ act more comprehensively ${ }^{(19)}$.

The action of an essential oil in the body will depend on the pathways by which the molecules are administered, which can occur through inhalation, ingestion or cutaneous pathways. When contact is made through inhalation, the molecules of EO stimulate the olfactory nerves which, in turn, have a direct link to the Limbic System ${ }^{(11)}$, responsible for emotions, feelings and motivational impulses. The "olfactory memory" results from an identification olfactory process, a specific aroma associating it with any memories triggered by the Limbic System.

Although the physiological mechanism of action of essential oils, and thus of Aromatherapy, is not well established, it is inferred that these molecules produce a system capable of releasing neurotransmitters stimulus, such as encephalin and endorphins, which generate an analgesic effect and produce a sense of wellness and relaxation ${ }^{(20)}$. Researches indicate that the olfactory stimulation produces immediate changes in physiological parameters such as blood pressure, pulse rate, muscle tension, pupil dilation, body temperature, blood flow, electrodermal activities and cerebral activities. However, the effects of aromatherapy of essential oils are not well supported through scientific clinical studies ${ }^{(21)}$.

When an essential oil molecule is inhaled, it crosses the upper respiratory tract, reaching the lower airways where it is absorbed by the pulmonary blood vessels and spread in the body through the bloodstream to organs and tissues ${ }^{(10)}$. When administered it through the skin, the molecules penetrate the skin or mucous membranes, where they are absorbed and distributed throughout the body tissues via the bloodstream. When ingested, their molecules penetrate the intestinal mucosa, reach the bloodstream and are distributed in the body ${ }^{(10)}$.
In the last two mentioned activities pathways, there is the action of the active ingredient present in the essential oil, in addition to nervous and sensory stimulation. As shown in Figure 1, even if it is administered by a pathway other than inhalation, always some oil molecules are released into the environment due to its low molecular weight, which will cause an olfactory stimulus and action on the respiratory system.

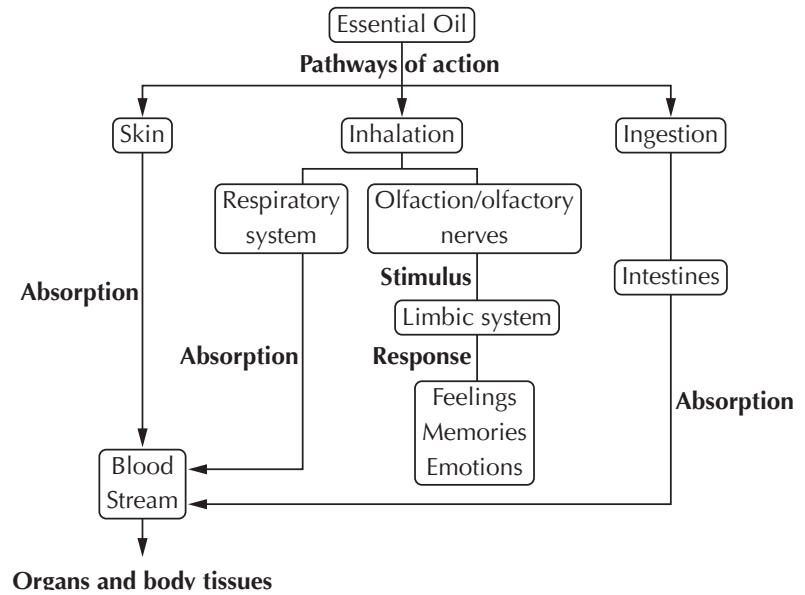

Figure 1 - Flowchart demonstrating the potential of $\mathrm{HI}$ performance pathways in the body - São Paulo, 2015.

Some essential oils also have antimicrobial effect, probably for its role in the cell wall structure of the microorganism, denaturing and coagulating proteins. The action would occur because it would alter the permeability of the cytoplasmic membrane due to its lipophilic characteristic, interrupting the vital processes of the cell, such as electron transport, translocation of protein phosphorylation and other enzymedependent reactions, and such actions would result in loss of chemiosmosis control of the affected cell, destroying it ${ }^{(22)}$.

Studies have been conducted with energetic measurements of essential oils using Raman spectroscopy ${ }^{(23-24)}$, which is based on the incidence of a monochromatic light source which, upon reaching the oil in question undergoes scattering of light, allowing researchers to obtain information about the chemical compound indicating that the components show energy bands. These studies support the existence of energy in essential oils, proposing that the use of these plant concentrates can act in line or changing energy patterns of an organism.

\section{AROMATHERAPY IN NURSING: HISTORICAL CONCEPT}

Florence Nightingale was a pioneer in Nursing when he introduced $\mathrm{EO}$ in the care process. She was responsible for indicating the application of essential oil of lavender ( $\mathrm{La}$ vandula angustifolia) in the frontal region of the wounded soldiers during the Crimean War in order to calm them ${ }^{(25)}$.

Although Nightingale was the first nurse to use EO in Nursing care, the first aromatherapist Nurse was Marguerite Maury, currently seen as an icon of modern Aromatherapy ${ }^{(19)}$. Maury was born in Austria in 1895, she graduated in Nursing and surgical assistant. She moved to France, where she came into contact with Aromatherapy. By the 
1930s, she met Dr. Maury, a doctor who was interested in natural therapies, and together they began to study the ICP. Marguerite is recognized as a reference in Aromatherapy because she integrated the principles of holistic Nursing the preparation of individual therapeutic prescriptions EO massage ${ }^{(26)}$ and developing the idea that a blend (mixture) of single EO could be developed for each person ${ }^{(17)}$.

With her studies, Marguerite Maury attempted to demonstrate the performance of $\mathrm{EO}$ on the nervous system, especially in the Limbic System, and taught courses and lectures throughout Europe on the $\mathrm{EO}$ mechanisms of action. She opened the first aromatherapy clinic in London ${ }^{(26)}$ and, later, others in France and Switzerland. Because Marguerite has developed studies on the action of EO in the body, she has become best known as a biochemist than a Nurse.

\section{AROMATHERAPY IN NURSING: THEORETIC FRAMEWORK}

Using EO is in accordance with the practical philosophy of the theories and the ethical principles that composes Nursing, allowing the integration of Aromatherapy to the values of the profession. Due to the emphasis on individual choice and uniqueness, choosing an essential oil, the Nurse must focus her/his attention in particular interaction with each person, acting as a partner with her/his customer, developing a treatment plan aimed at health promotion and well-being ${ }^{(17)}$.

Authors have already proposed the theoretical framework of Aromatherapy according to three Nursing Theories $^{(17)}$. The first correlation made was from the perspective of the model of Florence Nightingale Nursing care, which is grounded in attention to aspects of the environment. The environment plays an important role and contributes as a facilitator to natural healing and restoration of the patient. For this reason, Florence indicated the use of lavender essential oil in the frontal region of wounded fighters ${ }^{(25)}$, with the intention of providing comfort and relief, making a suitable environment to allow the recovery process. Aromatherapy can permeate three environmental aspects: ventilation and cleanliness, rest and relaxation, and changes in environmental conditions. In relation to ventilation and cleanliness, intervention can be accomplished through environmental diffusion of $\mathrm{EO}$ with antiseptic properties, diluted with distilled water such as eucalyptus (Eucalyptus globulus), lemon (Citrus limonum) or tea tree (Melaleuca alternifolia) ${ }^{(17)}$.

Some EO contribute to relaxation and improved sleep. Lavender oils (Lavandula angustifolia) or chamomile (Anthemis nobilis) can be directly applied to the skin by means of massage, diluted in a carrier oil such as almond or jojoba oil, or even inhaled. Applying a drop of lavender oil ( $\mathrm{La}-$ vandula angustifolia), chamomile (Anthemis nobilis) or sweet marjoram (Origanum marjorana) on a cotton ball placed inside the pillow can help increase relaxation and sleep ${ }^{(17)}$.

The oppressive and monotonous environments of hospitals and health care centers can be changed through a sensory olfactory variation by using EO. The happy notes of orange (Citrus sinensis) or grapefruit (Citrus paradisi), geranium (Pelargonium graveolens) or rose (Rosa damascena), or refreshing rosemary flavor (Rosmarinus officinalis), or basil (Ocimum basi- licum) can be dispersed in the environment through the use of a diffuser as change the perception of patients regarding the environment where they are living in. Because the scents stimulate olfactory memory, the Nurse may involve the client in choosing scents that evoke memories and good feelings ${ }^{(17)}$.

According to some authors, the second Theory of Nursing that may be reflected in the light of Aromatherapy is Jean Watson's theory ${ }^{(17)}$. This theorist defines that healing is enhanced by transpersonal care, and in that sense, aromatherapy can be offered in conjunction with the touch, massage or through the gentle application directly to the skin. Thus, the human connection by touch is stated as part of the practice of Aromatherapy. For Watson, health is conceptualized as an integral harmony in the interrelationship person-environment, and EO can create a sense of harmony with the environment because they are organic elements that work in harmony with the body ${ }^{(17)}$.

In Watson's Theory care is holistic, interactive and based on the transpersonal service, which consists of the unitary field of consciousness and energy, transcending time, space and physicality, translating into an energetic interaction that occurs between Nurse and patient. The healing process, which should not be only understood as a cure but also as restoration/rebuilding of being, is inserted in a non-invasive environmental energy field ${ }^{(27)}$, in this sense, Aromatherapy fits well as Nursing intervention, since it is a holistic ICP with grounds which may be used environmentally or in a non-invasive way. EO may have a normalizing action - in the case of hyssop (Hyssopus officinalis), which is suggested as a pressure regulator for both hyper and for hypotension, and ylang ylang (Cananga odorata), which can be applied in states of depression or increased activity or agitation ${ }^{(17)}$.

In the light of the third Theory proposed by other authors ${ }^{(17)}$, according to Martha Rogers, Nursing is considered a humanistic and humanitarian science, focused on the description and explanation of the human being as a whole synergistic. The principles of this theory are based on integrality, resonance and helicity and address the concepts of energy fields in constant exchange, like open systems, it is not possible to separate the human from the environment where they live in ${ }^{(27)}$. Given this assumption, Aromatherapy reflects the interrelationship between plants and people, since the energy pattern of the people exerts a dynamic exchange with the energy pattern of the plant, which is encoded in the essential oil. Each essential oil may be seen as a pattern of single vibrational frequencies, in the same manner that each individual is considered a unique pattern of energy frequencies, as proposed by Rogers.

The process of change must be produced by the active participation of the Nurse and the patient. In partnership, both can select EO to act as facilitators in this process, based on personal choices and experiences. Patchouli oil (Pogostemom patchouli), for example, helps to connect with the earth, bringing a sense of security; oils derived from citrus such as bergamot, orange and grapefruit may increase concentration and improve mood. Other EO used frequently to balance and harmonize energy fields are the frankincense (Boswellia carteri) and ylang ylang ${ }^{(17)}$. 
In addition to the aforementioned three theories that have been related by other authors ${ }^{(17)}$, it is possible to identify rational-theoretical aspects of the Aromatherapy in five other theories and assist with this understanding: Myra Levine, Hildegard Peplau, Callista Roy, Wanda Horta and Katharine Kolcaba. Aromatherapy can be used as a device for restoring the individual with the environment they live in, helping to improve the body's response to stress agents. It is proposed by Myra Levine that the nurse should be aware of the dependence and interaction between the individual and the environment, helping in the process of personal transformation and preventing the stress caused by an imbalance among the operating standards of the human body, which promotes its integrity ${ }^{(27)}$.

Using EO contributes to the maintenance of the four conservation principles proposed by Levine. The principle of energy conservation, for example, using the essential oil of rosemary (Rosmarinus officinalis) to provide more disposition $^{(17)}$; the principle of conservation of structural integrity, with the use of lavender or tea tree oil to promote epithelial healing. The essential tea tree oil has been shown to be a promising agent in the nursing field, especially in stomatherapy. Nurses conducted a study demonstrating that it can assist in the healing of infected wounds ${ }^{(28)}$. The principle of conservation of personal integrity is given through aid in decision making, and if so, it can use Patchouli to bring security ${ }^{(17)}$. An essential oil can be used in order to promote increased social interaction, converging with the principle of conservation of social integrity, which can be afforded by the environmental use of orange oil ${ }^{(10)}$.

In the Theory of Interpersonal Relations, developed by Hildegard Peplau, Nursing should focus on support to interpersonal relationships for the care situations that can be turned into learning experiences and personal growth, which are shared by the Nurse and the patient ${ }^{(27)}$. To assist the patient in coping with stressful situations, the Nursing intervention can be accomplished through the use of Melissa oil (Melissa officinalis), which contributes to the handling of situations that generate emotional trauma ${ }^{(10)}$.

Callista Roy proposes a model in which the person is understood as a system capable of creating changes to adapt themselves to the environment in which the individual's adaptation level depends on the skill and mobilization ability to make changes. In this case, Aromatherapy can be a tool to assist in the adaptation process and coping ${ }^{(27)}$. An example would be the use of geranium oil (Pelargonium graveolens), which may be used to stabilize emotions events caused by traumas ${ }^{(17)}$. For orthopedic patients who have lost autonomy and suffer from low self-esteem, the ylang ylang and rose oils (Rosa Damascena) help to deal with the emotional trauma and improve self-esteem ${ }^{(10,16)}$.

Supported by the Nursing Theories, Aromatherapy can act as an instrument to assist in restoring balance, as proposed by the Brazilian theorist Wanda Horta ${ }^{(27)}$. In this sense, bergamot essential oil (Citrus bergamia) could be used as an environmental diffuser or during bath in order to reduce anxiety and improve depressive and sadness states, besides providing a refreshing sensation, contributing to restoring the balance ${ }^{(10)}$.

Finally, the Theory likely to relate to the Aromatherapy is the Comfort Theory, described by Katharine Kolcaba. For this theorist, the Nurse should assess and identify the patient's comfort needs in physical, psycho-emotional, social spheres and environmental context, which are not being met by proposing an intervention that includes meeting the individual needs holistically ${ }^{(29)}$. In this sense, Aromatherapy can act as a Nursing intervention to improve patient comfort of their family or community, both in the management of psycho-physical, emotional, and environmental areas, promoting relief, tranquility and transcendence which result in a state of well-being. Physical pain can be alleviated through the environment use of clove oil (Syzygium aromaticum), for example, which also has antiseptic properties. Anxiety states can be reduced using lavender oil in the bath or massage. Recently, a study conducted by Nurses has pointed out that Aromatherapy, applied through massage with lavender oil, has proven to be effective in relieving anxiety in patients with personality disorder in psychiatric hospitalization, which could be observed by reduction in heart rate and respiratory participants ${ }^{(30)}$.

Social interactions can be encouraged by using citrus oils, which give an appearance of lightness and joy to the environment.

Aromatherapy, based on Nursing Theories, should follow the assumption that the EO must support the harmonious integration in the human-environment relationship ${ }^{(17)}$. From the foregoing, we propose a Summary Chart (Chart 1), supporting Aromatherapy in the theoretical concepts proposed by the aforementioned Nursing theorists.

Chart 1 - Aromatherapy grounds according to the theoretical concepts proposed by the Nursing theories - São Paulo, 2015.

\begin{tabular}{|l|l|l|}
\hline Author/Theorist & Nursing theories & Association of theoretical principles with Aromatherapy \\
\hline $\begin{array}{l}\text { Florence Nightingale } \\
(1820-1910)\end{array}$ & Environmentalist Theory & $\begin{array}{l}\text { Promotes environmental cleaning, relaxation and acts on variations of } \\
\text { environmental sensations as a stimulus }\end{array}$ \\
\hline Myra Estrin Levine (1967) & Holistic Theory & $\begin{array}{l}\text { Assists in the individual transformation process, preventing the stress } \\
\text { caused by an imbalance change in the harmonious functioning of the body, } \\
\text { promoting its integrity }\end{array}$ \\
\hline Hildegard Peplau (1952) & $\begin{array}{l}\text { Theory of Interpersonal } \\
\text { Relations }\end{array}$ & Acts as a support to interpersonal relationships \\
\hline Martha Rogers (1970) & $\begin{array}{l}\text { Theory of Human unit } \\
\text { - conceptual model of } \\
\text { Mankind }\end{array}$ & $\begin{array}{l}\text { Associated with care, assist individuals to reach their maximum health } \\
\text { potential, both physical and emotional scope }\end{array}$ \\
\hline Sister Callista Roy (1970) & Adaptation Theory & Assisting instrument in the adaptation process inherent to life changes \\
\hline
\end{tabular}


...continuation

\begin{tabular}{|l|l|l|}
\hline Author/Theorist & Nursing theories & Association of theoretical principles with Aromatherapy \\
\hline Wanda de Aguiar Horta (1970) & $\begin{array}{l}\text { Theory of Basic Human } \\
\text { Needs }\end{array}$ & Instrument able to restore balance to meet human needs \\
\hline Katharine Kolcaba (2003) & Comfort Theory & $\begin{array}{l}\text { Instrument able to promote patient comfort in physical, psycho-emotional, } \\
\text { social and environmental context }\end{array}$ \\
\hline Jean Watson (2005) & $\begin{array}{l}\text { Theory of Transpersonal } \\
\text { Care }\end{array}$ & $\begin{array}{l}\text { Promotion and restoration of health through changes in the patient's energy } \\
\text { field of the interrelationship with the environment standards }\end{array}$ \\
\hline
\end{tabular}

Based on Chart 1 and on the premise that Aromatherapy can be a device applied in order to change an energetic pattern of an individual, helping to improve their emotional state, it can be said that ICP is likely to be based in Nursing Theories. Thus, it is proposed that this practice is used as a nursing intervention instrument, as EO provide physical and psycho-emotional action.

\section{FINAL CONSIDERATIONS}

The interfaces found between the applicability of Aro- matherapy and Nursing Theories contribute to the dissemination and implementation of this therapy in the context of Nursing care. Humanistic and holistic principles, guided in interpersonal relationships and in the integral approach of the human being is discussed in the current context of Nursing, find accordance with complementary practices such as Aromatherapy, contributing to the expansion of care towards offering an approach that reaches not only the physical, but mental, emotional and spiritual well-being of the patients.

\section{RESUMO}

A Aromaterapia é uma Prática ou Terapia Complementar de saúde que utiliza concentrados voláteis extraídos de plantas, os chamados óleos essenciais, com a finalidade de melhorar o bem-estar físico, mental e emocional. A Aromaterapia tem sido praticada histórica e mundialmente por Enfermeiros e, visto que no Brasil sua utilização possui respaldo pelo Conselho Federal de Enfermagem, torna-se relevante discutir essa prática no contexto da Enfermagem por meio das Teorias da Enfermagem. O presente estudo de reflexão teórica, exploratório e descritivo, tem como objetivo discorrer sobre a farmacognosia dos óleos essenciais, a trajetória histórica da Aromaterapia na Enfermagem e fundamentar a Aromaterapia à luz de oito Teoristas de Enfermagem (Florence Nightingale, Myra Levine, Hildegard Peplau, Martha Rogers, Callista Roy, Wanda Horta, Jean Watson e Katharine Kolcaba), contribuindo para a sua inserção como prática assistencial da profissão.

\section{DESCRITORES}

Aromaterapia; Terapias Complementares, Óleos Voláteis; Enfermagem; Teoria de Enfermagem.

\section{RESUMEN}

La Aromaterapia es una Práctica o Terapia Complementaria de salud que utiliza concentrados volátiles extraídos de plantas, los llamados aceites esenciales, con el fin de mejorar el bienestar físico, mental y emocional. La Aromaterapia ha sido practicada histórica y mundialmente por Enfermeros y, a la vista de que su empleo en Brasil tiene respaldo del Consejo Federal de Enfermería, se hace relevante discutir dicha práctica en el marco de la Enfermería mediante las Teorías de la Enfermería. El presente estudio de reflexión teórica, exploratorio y descriptivo tiene como objetivo discurrir acerca de la farmacognosia de los aceites esenciales, la trayectoria de la Aromaterapia en la Enfermería y fundamentar la Aromaterapia a la luz de ocho Teóricos de la Enfermería (Florence Nightingale, Myra Levine, Hildegard Peplau, Martha Rogers, Callista Roy, Wanda Horta, Jean Watson y Katharine Kolcaba), contribuyendo a su inserción como práctica asistencial de la profesión.

\section{DESCRIPTORES}

Aromaterapia; Terapias Complementarias; Aceites Volátiles; Enfermería; Teoría de Enfermería.

\section{REFERENCES}

1. National Center for Complementary and Alternative Medicine. Complementary, alternative, or integrative health: what's in a name? [Internet]. Bethesda; 2008 [cited 2014 July 21]. Available from: http://nccam.nih.gov/health/whatiscam

2. Luz MT. Novos saberes e práticas em saúde coletiva: estudo sobre racionalidades médicas e atividades corporais. $3^{a}$ ed. São Paulo: Hucitec; 2007.

3. World Health Organization. General guidelines for methodologies on research and evaluation of traditional medicine. Geneva: WHO; 2000.

4. World Health Organization. WHO traditional medicine strategy: 2002-2005. Geneva: WHO; 2002.

5. World Health Organization. WHO traditional medicine strategy: 2014-2023. Geneva: WHO; 2014.

6. Brasil. Ministério da Saúde. Portaria n. 971/2006. Aprova a Política Nacional de Práticas Integrativas e Complementares (PNPIC) no Sistema Único de Saúde. Diário Oficial da União, Brasília, 4 maio 2006. Seção 1, p. 20-5.

7. Brasil. Ministério da Saúde. Portaria n. 2.543/1995. Regulamenta a formação do Grupo Assessor Técnico-Científico em Medicinas nãoConvencionais, editada pela então Secretaria Nacional de Vigilância Sanitária do Ministério de Saúde. Diário Oficial da União, Brasília, 15 dez. 1995. Seção 1, p. 21167. 
8. Brasil. Ministério da Saúde. Relatório final da $10^{a}$ Conferência Nacional de Saúde, Brasília-DF, de 2 a 6 de setembro de 1996 . Brasília: Conselho Nacional de Saúde; 1998.

9. Brasil. Ministério da Saúde. Política Nacional de Medicina Natural e Práticas Complementares (PNMNPC). Brasília; 2005.

10. Tisserand R. The art of aromatherapy. 2nd ed. Saffron Walden: CW Daniel; 2004.

11. Walters C. Illustrated elements of aromatherapy. New York: Metro Books; 1998.

12. Brasil. Senado Federal. Projeto de Lei n. 64 de 2009. Dispõe sobre a regulamentação do exercício das atividades de terapias, a criação do Conselho Federal de Terapeutas e dos Conselhos Regionais de Terapeutas, suas atribuições e responsabilidades, e dá outras providências [Internet]. Brasília; 2009 [citado 2015 jul. 21]. Disponível em: http://www.senado.leg.br/atividade/materia/getTexto.asp?t=61207

13. Conselho Federal de Enfermagem (COFEN). Resolução COFEN 197/1997. Estabelece e reconhece as Terapias Alternativas como especialidade e/ou qualificação do profissional de Enfermagem [Internet]. Brasília; 1977 [citado 2015 jul. 21]. Disponível em: http:// www.cofen.gov.br/resoluo-cofen-1971997_4253.html

14. Conselho Federal de Enfermagem (COFEN). Resolução COFEN 389/2011. Atualiza, no âmbito do sistema COFEN/Conselhos Regionais de Enfermagem, os procedimentos para registro de títulos de pós-graduação lato e stricto sensu concedidos a Enfermeiros e lista especialidades [Internet]. Brasília; 2011 [citado 2015 jul. 21]. Disponível em: http://www.cofen.gov.br/resoluo-cofen-n-3892011_8036.html

15. Almeida VCF, Lopes MVO, Damasceno MMC. Teoria das relações interpessoais de Peplau: análise pautada em Barnaum. Rev Esc Enferm USP. 2005;39(2):202-10.

16. Gnatta JR, Zotelli MFM, Carmo DRB, Lopes CLBC, Rogenski NM, Silva MJP. The use of aromatherapy to improve self-esteem. Rev Esc Enferm USP [Internet]. 2011 [cited 2015 July 21];45(5):1113-20. Available from: http://www.scielo.br/pdf/reeusp/v45n5/en_v45n5a12.pdf

17. Smith MC, Kyle L. Holistic foundations of aromatherapy for nursing. Holist Nurs Pract. 2008;22(1):3-9.

18. Bakkali F, Averbeck S, Averbeck D, Idaomar M. Biological effects of essential oils - a review. Food Chem Toxicol. 2008;46(2):446-75.

19. Corazza S. Aromacologia: uma ciência de muitos cheiros. São Paulo: SENAC; 2002.

20. Potts J. Aromatherapy in nursing practice. Aust Nurs J. 2009;16(11):55.

21. Kamkaen N, Ruangrungsi N, Patalung NN, Watthanachaiyingcharoen R. Physiological and psychological effects of lemongrass and sweet almond massage oil. J Health Res. 2015;29(2):85-91.

22. Dorman HJ, Deans SG. Antimicrobial agents from plants: antibacterial activity of plant volatile oils. J Appl Microbiol. 2000; 88(2):308-16.

23. Baranska M, Schulz H, Reitzenstein S, Uhlemann U, Strehle MA, Krüger H et al. Vibrational spectroscopic studies to acquire a quality control method of Eucalyptus essential oils. Biopolymers. 2005;78(5):237-48.

24. Schulz H, Baranska M, Quilitzsch R, Schütze W, Lösing G. Characterization of peppercorn, pepper oil, and pepper oleoresin by vibrational spectroscopy methods. J Agric Food Chem. 2005;53(9):3358-63.

25. McDowell B. Nontraditional therapies for PICU. J Pediatr Nurs. 2005;10(1):29-32.

26. Andrei P, Del Comune AP. Aromaterapia e suas aplicações. Centro Universitário São Camilo. 2005; 11(4):57-68.

27. McEwen M, Wills E M. Bases teóricas para enfermagem. Porto Alegre: Artmed; 2009.

28. Chin KB, Cordell B. The effect of tea tree oil (Melaleuca alternifolia) on wound healing using a dressing model. J Altern Complement Med. 2013;19(12):942-5.

29. Kocalba K. Comfort theory and practice: a vision for holistic health care and research. New York: Springer; 2003.

30. Domingos TS, Braga EM. Massage with aromatherapy: effectiveness on anxiety of users with personality disorders in psychiatric hospitalization. Rev Esc Enferm USP [Internet]. 2015 [cited 2015 July 21];49(3):450-6. Available from: http://www.scielo.br/pdf/reeusp/ v49n3/0080-6234-reeusp-49-03-0453.pdf 